\title{
Envelope development and variation in Trachelomonas hispida (Euglenophyta)
}

\author{
Malgorzata Poniewozik ${ }^{1, *}$, Emil Zięba $^{2}$ and Ewa Sajnaga ${ }^{3}$ \\ ${ }^{1}$ Department of Plant Physiology and Biotechnology, Faculty of Biotechnology and Environmental Sciences, The John \\ Paul II Catholic University of Lublin, Konstantynów 1i, PL-20-708 Lublin, Poland \\ ${ }^{2}$ Laboratory of Confocal and Electron Microscopy, Centre for Interdisciplinary Research, The John Paul II Catholic \\ University of Lublin, Konstantynów 1j, PL-20-708 Lublin, Poland \\ ${ }^{3}$ Laboratory of Biocontrol, Production and Application of Entomopathogenic Nematodes, Centre for Interdisciplinary \\ Research, The John Paul II Catholic University of Lublin, Konstantynów 1j, PL-20-708 Lublin, Poland
}

In Trachelomonas hispida, the adult envelope that surrounds the monad is oval in shape and covered with spines. Development of the lorica is an interesting, but poorly known phenomenon. We observed in detail the formation of spineless envelopes of T. hispida using light microscopy and scanning electron microscopy. The results showed that young cells formed delicate and net-like envelopes. The structure changed with age, and mature specimens had solid, thick loricae with small pores. As the loricae aged, they changed their shape, and rope-like fibres from the external layer started to unwind, progressing from the apical pore, exposing the underlying net-like structure. X-ray spectrometry showed that Fe was the major mineral component in young and mature loricae, whereas old loricae did not contain Fe salts, although they did contain a high number of Mn compounds. We also noticed a different pattern of mineralization process in the envelopes. Apart from the even distribution of mineral deposition over the entire lorica, we observed that it started from the apical pore and ended at the posterior end. There was considerable morphological variation in envelope shape and ornamentation, which had collars and folds around the apical pore and process at the posterior end. This suggested that many varieties of $T$. hispida should be taxonomically reappraised. We also discuss a hypothetical role for the spines on lorica surfaces in aquatic ecosystems.

Key Words: envelope; euglenoids; Euglenophyceae; lorica formation; Trachelomonas hispida

Abbreviations: EDS, energy dispersive spectroscopy; EDX, energy-dispersive X-ray; JM : SE, Jaworski's medium with soil extract; PCR, polymerase chain reaction; SEM, scanning electron microscopy; SSU rRNA, small nuclear subunit of the ribosomal RNA

\section{INTRODUCTION}

Cells of the euglenoids Trachelomonas, Strombomonas, and Ascoglena form external envelopes (loricae) from the copious amount of mucopolysaccharides that are produced and secreted over the entire protoplast through muciferous bodies (Donnelly Barnes et al. 1986, Conforti et al. 1994). Thereafter, initially thin and delicate loricae become saturated, mainly with $\mathrm{Fe}$ and / or $\mathrm{Mn}$ compounds, resulting in a rigid structure of a fully-de-
(P) $\$$ This is an Open Access article distributed under the terms of the Creative Commons Attribution Non-Commercial License (http://creativecommons.org/licenses/by-nc/3.0/) which permits unrestricted non-commercial use, distribution, and reproduction in any medium, provided the original work is properly cited.
Received March 20, 2018, Accepted November 9, 2018

*Corresponding Author

E-mail: gonium@kul.pl

Tel: +48-81-45-45-416, Fax: +48-81-44-54-611 
veloped cell (Leedale 1975, West et al. 1980a, Dunlap and Walne 1985, Donnelly Barnes et al. 1986). The envelopes vary in size, shape, and appearance of external ornamentation. The appearance of loricae (shape, and presence or absence of a collar, or thickening around the apical pore at the anterior end, and the external structure of the envelopes) is still used as the main criterion in species identification (Starmach 1983, Dunlap and Walne 1987, Wołowski 1998, Conforti 1999, Dillard 2000, Wołowski and Hindák 2003).

There are many examples in nature of organisms at different levels of organization and evolution that form hardened structures from protists to vertebrates, whose bones are shaped and hardened during the calcification process, which become mineralized during subsequent stages of development (e.g., Francillon-Vieillot et al. 1990, Pentecost 1991, Bilan and Usov 2001, Sviben et al. 2018). Among the algae, there are several groups of taxa with solid, mineralized structures that are an integral part of their cells. Silicification is the most common process; for example, diatoms have silicified cell walls in the form of two frustules of varying shape and intricate nanoarchitecture (Müller 2012, Hildebrand and Lerch 2015), and chrysophytes that produce overlapping siliceous scales that cover their cells and stomatocysts (Preisig 1994, Sandgren et al. 1996). Euglenophytes produce envelopes that are mineralized using Fe and Mn, although some $\mathrm{Si}$ in envelopes has also been documented (West et al. 1980a, Dunlap et al. 1986, Conforti et al. 1994, Pereira et al. 2003, Wang et al. 2003, Poniewozik 2017). The role of hardened structures is debatable, as there are multiple possibilities (Milligan and Morel 2002, Raven and Waite 2004, Mitchell et al. 2013, Ellegaard et al. 2016). However, envelopes might be a good defence against predators (Hamm et al. 2003) and function as armour for algae, especially diatoms, which are evolutionarily successful in aquatic habitats worldwide. Envelope structures are an example of special adaptations, which have been observed in different groups of organisms, that enable them to compete with other organisms that also have unique adaptations. However, the purpose of euglenoid envelopes remains unknown.

Although there are many studies showing details (scanning electron microscopy [SEM] analysis) of the external structures of trachelomonad loricae (e.g., Brosnan et al. 2005, Wołowski and Walne 2007, Conforti 2010, Solórzano et al. 2011, Duangjan and Wołowski 2013, Poniewozik 2016), relatively little is known about how they are formed. The first examination of this process was presented by Pringsheim (1953), who described 'thick,' 'solid,' and 'ornamented' stages in the formation of new lorica from thin and colourless to mature. In other studies, the role of $\mathrm{Fe}$ and / or $\mathrm{Mn}$ in the formation of the solid structure was demonstrated (West and Walne 1980, West et al. 1980a, Dunlap et al. 1983, Dunlap and Walne 1985, 1987, Pereira et al. 2003). The most comprehensive work was published by Brosnan et al. (2005), who examined loricae development and formation in eight species of Trachelomonas and compared the stages of formation with those in Strombomonas taxa. Although different types of trachelomonad loricae (round, oval, with spines, spineless, porous, colourless, similar to strombomonad loricae) were studied, there were no Trachelomonas hispida loricae (Brosnan et al. 2005). The loricae of T. hispida var. coronata were examined to establish the pattern of strip reduction at the anterior and posterior poles of the trachelomonad pellicle. West et al. (1980a, 1980b) examined envelopes in a single variety of $T$. hispida var. coronata, specifically (1) envelope substructure including details of the inner wall structure (West and Walne 1980); (2) mineral composition of envelopes, which showed that $\mathrm{Mn}$ content depended on the colour of the envelope (West et al. 1980a); and (3) the ultrastructure of the cytoskeletal and flagellar systems (West et al. 1980b).

This study was focused on the outer wall of the lorica in one of the most widespread taxon, T. hispida, which develops a spiny-surfaced wall lorica in natural ecosystems. We analysed the variation in loricae of $T$. hispida at different stages of development-from young, through mature, to old cells. Additionally, we investigated whether the lorica wall had different chemical compositions at different ages. We provided further information about trachelomonad loricae to that one provided previously (Pringsheim 1953, Leedale 1975, Dunlap et al. 1986, Conforti et al. 1994, Brosnan et al. 2005).

\section{MATERIALS AND METHODS}

This study used Trachelomonas hispida (Perty) F. Stein culture CCAP 1283/8, which was obtained from the Culture Collection of Algae \& Protozoa, Dunstaffnage Marine Laboratory, Oban, Scotland, UK. Specimens were grown in Jaworski's medium with soil extract (JM : SE) (Thompson et al. 1988). Since the strain did not develop a mature lorica with spines, which was unusual, we checked what impact on lorica appearance has the water from the natural environment where trachelomonads were found. We placed the culture in water that was collected from six different water bodies in eastern Poland (lakes Glinki, 
Miejskie, Piaseczno, Rotcze, Sumin, and the Zalew Zemborzycki dam reservoir) and filtered using a GF/C and then a $0.22-\mu \mathrm{m}$ Millipore syringe filter (Merck Millipore, Burlington, MA, USA). The water bodies differed in water colour, nutrients, and organic carbon content (Table 1). Cultures were incubated at $21-22^{\circ} \mathrm{C}$ on a $12: 12-\mathrm{h}$ light : dark cycle with illumination at $35-36 \mu \mathrm{mol} \mathrm{m}^{-1} \mathrm{~s}^{-1}$ provided by $40 \mathrm{~W}$ 'cool white' fluorescent bulbs. The experiment duration was four weeks, we supplemented the cultures every week by adding $3 \mathrm{~mL}$ of fresh medium to avoid mineral depletion. Samples for SEM analyses were prepared according to the procedures described by Bozzola and Russell (1995). The fixed material was washed several times using distilled water to remove buffer salts and then samples were dehydrated using a graded ethanol series. Afterwards, drops of dehydrated material were transferred to slides mounted on aluminium stubs ( $10.0 \mathrm{~mm}$ ) with graphite coating and air-dried overnight at about $20^{\circ} \mathrm{C}$. After drying, the stubs were sputter-coated using a 20-nm cover of carbon using a Cressington sputter-coater (Cressington Scientific Instruments Ltd., Watford, UK). SEM observations of carbon-coated material were made using a Hitachi S-4700 microscope (Hitachi, Tokyo, Japan) (field samples). Microscopic images (culture samples) were made using a field emission scanning electron microscope Zeiss model Ultra Plus (Zeiss $\mathrm{GmbH}$, Oberkochen, Germany). Samples were placed in a chamber on $12.5 \mathrm{~mm}$ aluminium stubs, pressure was applied to $5 \times 10^{-4} \mathrm{~Pa}$. Images was recorded at $20 \mathrm{keV}$ electron beam energy, 30-microns aperture and $9 \mathrm{~mm}$ working distance. For quantitative, qualitative and elements mapping an energy-dispersive X-ray (EDX) detector with real resolution $123 \mathrm{eV}$ was used (model $125 \mathrm{eV}$; Bruker AXS, Berlin, Germany). Characteristic radiation signal of elements was collected from detector over 100 s live-time (spectra) and over 10 min live-time (maps) in Quantax software (Bruker) to visualize and interpret the

Table 1. Physicochemical properties of the lake waters used for cultivation of the Trachelomonas hispida strain

\begin{tabular}{|c|c|c|c|c|}
\hline Lake & $\begin{array}{c}\text { Water colour } \\
\left(\mathrm{mgPt} \mathrm{L}^{-1}\right)\end{array}$ & $\begin{array}{c}\text { DOC } \\
\left(\mathrm{mgC} \mathrm{L}^{-1}\right)\end{array}$ & $\begin{array}{c}\mathrm{P}-\mathrm{PO}_{4} \\
\left(\mathrm{mg} \mathrm{L}^{-1}\right)\end{array}$ & $\begin{array}{l}\mathrm{N}-\mathrm{NH}_{4} \\
\left(\mathrm{mg} \mathrm{L}^{-1}\right)\end{array}$ \\
\hline Glinki & 234 & 5.30 & 0.272 & 1.143 \\
\hline Miejskie & 48 & 1.32 & 0.283 & 0.547 \\
\hline Piaseczno & 20 & 0.68 & 0.109 & 0.270 \\
\hline Rotcze & 12 & 0.80 & 0.322 & 0.406 \\
\hline Sumin & 45 & 2.30 & 0.334 & 0.579 \\
\hline $\begin{array}{l}\text { Zalew } \\
\text { Zemborzy }\end{array}$ & 14 & 0.42 & 0.209 & 0.715 \\
\hline
\end{tabular}

DOC, dissolved organic carbon; $\mathrm{P}-\mathrm{PO}_{4}$, inorganic phosphorus; $\mathrm{N}-\mathrm{NH}_{4}$, ammonium nitrogen. qualitative, quantitative and map data. EDX spectra and elemental maps were recorded for selected fragments of samples and SEM photos of their surfaces were taken. Quantitative analysis of EDX spectra was carried out with the use of a "non-standard" method.

We conducted a molecular analysis to determine the taxonomic affinity of the strain. Total genomic DNA from the cell pellet was isolated using a DNeasy Blood and Tissue Kit (Qiagen, Hilden, Germany) following the animal tissues protocol. Amplification of the small nuclear subunit of the ribosomal RNA (SSU rRNA) gene was performed using the primers: ESssu_hisF 5'-TCAAGGATTAAGCCATGCATGT-3' and ESssu_hisR 5'-TTACGACTTTTGCTTCTAAG-3'. Polymerase chain reaction (PCR) amplifications were conducted using $5 \times$ FirePol Master Mix (Solis BioDyne, Tartu, Estonia) according to the manufacturer recommendations. PCR of the 18S rRNA gene was performed using the following thermal profile: initial denaturation at $95^{\circ} \mathrm{C}$ for $3 \mathrm{~min}, 30$ cycles of $30 \mathrm{~s}$ at $95^{\circ} \mathrm{C}, 45 \mathrm{~s}$ at $55^{\circ} \mathrm{C}, 2 \mathrm{~min}$ at $72^{\circ} \mathrm{C}$, and final extension for $8 \mathrm{~min}$ at $72^{\circ} \mathrm{C}$. The amplified products were purified using standard methods and sent to Genomed (Warsaw, Poland) for sequencing using the primers listed above, V4_F and V4_R (Łukomska-Kowalczyk et al. 2016). The nearly-whole-length sequence of the SSU gene was compared to homologous nucleotide sequences in GenBank using BLASTN program. Sequences were aligned using ClustalW and then adjusted manually using BioEdit software (Hall 2011). The resulting alignment was used to construct maximum likelihood method tree based on the Kimura 2-parameter model (Kimura 1980). All the phylogenetic analyses were conducted in MEGA 6.06 (Tamura et al. 2013). The best fit model was identified using jModelTest (Darriba et al. 2012). All positions containing gaps and missing data were eliminated. Tree topology was evaluated using 1,000 bootstrap replications. There were 2,030 positions in the final data set. The partial 18S rRNA gene sequence was deposited in the GenBank database under accession number MG757560.

\section{RESULTS}

\section{Morphology of loricae}

The loricae of T. hispida were more-or-less elliptical, with an apical pore surrounded by shorter or longer spines, or a short collar. Ornamentation included pores and spines. This description only applied to cells from natural populations (Fig. 1A-J). The cells cultivated under 

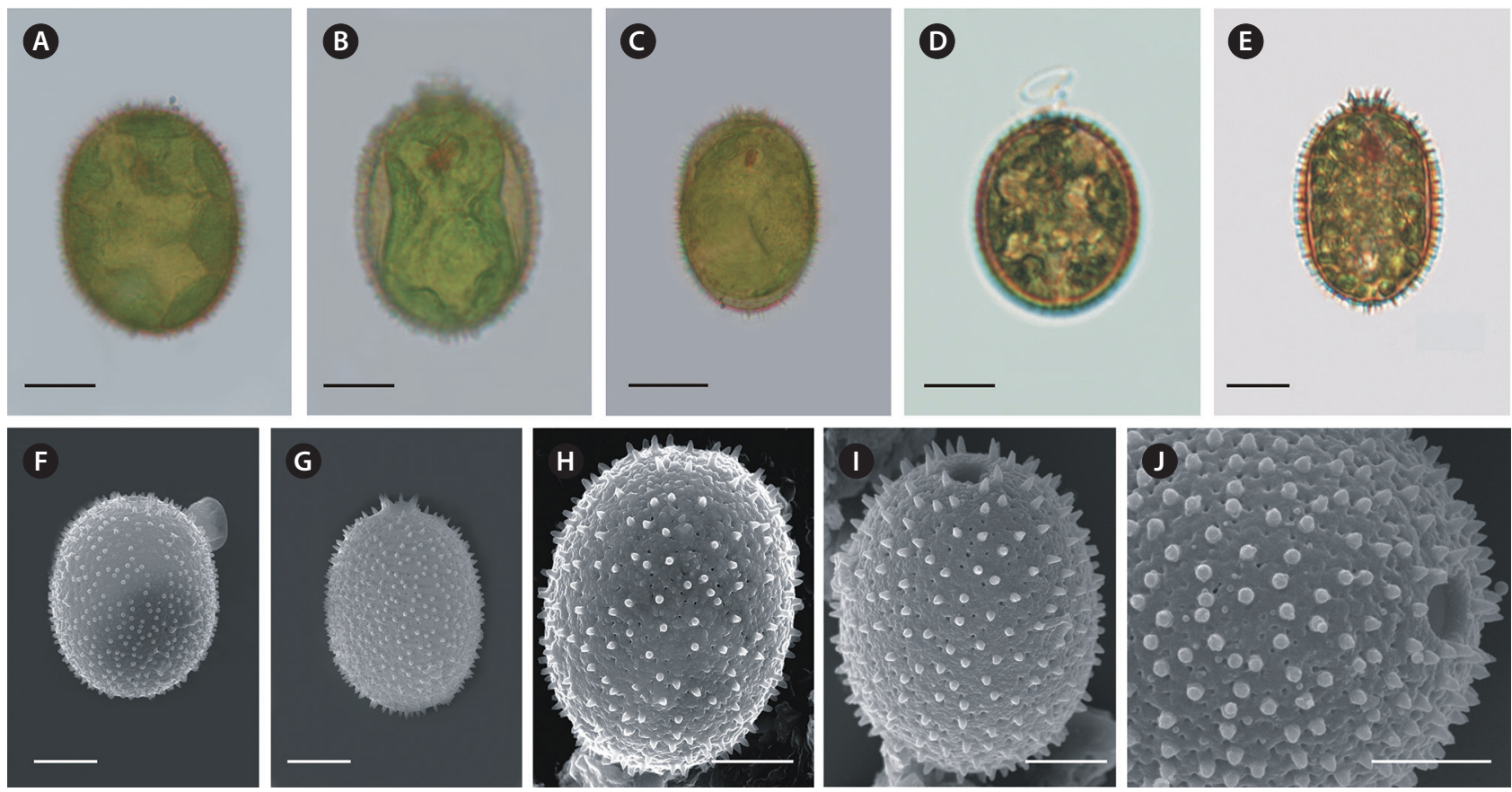

Fig. 1. Morphological details in spiny Trachelomonas hispida from the field samples. (A-E) Light microscopy pictures. (F-J) Scanning electron microscopy pictures. Pictures present loricae with $(B, C, E \&$ \&) or without $(A, D, F \& H-J)$ a collar, but all of them possess the entire lorica covered with more or less regularly distributed spines. Scale bars represent: A-J, $10 \mu \mathrm{m}$. [Colour figure can be viewed at http://www.e-algae.org].

laboratory conditions were usually of a different appearance. After leaving a parent lorica (Fig. 2A) a monad started dividing (Fig. 2B-E). Sometimes a monad divided into two offspring monads inside the lorica and then both, or rarely one, left the lorica. Then, the young monad (Fig. $2 \mathrm{~F}$ \& G) started building a new lorica. The process initiated from a very thin, hyaline layer (Fig. 2H \& I) that became saturated with mineral salts from the medium / water. In some cases, we observed the effects of the lorica mineralization process, which initiated from the anterior end of a very thin, colourless lorica and progressed to the posterior end (Fig. 2J). Finally, the lorica was evenly mineralized and coloured (Fig. 2K-T).

Although the culture originated from one cell, there was a large variety of lorica shapes. Most were regularly elliptic (Fig. 2J-O); however, in many cases, they were longitudinally elliptic (Fig. 2P), obovoid (Fig. 2S \& T), or had a visible process at the posterior end (Fig. 2R, T \& V). We observed that some loricae did not have a collar (Fig. $2 \mathrm{~K} \& \mathrm{~L}$ ), while others had an apical pore with a collar (Fig. $2 \mathrm{M}-\mathrm{T}$ ). The collar also had folds or ribs around the apical end, which were not clearly visible in live cells, only in empty envelopes or those with disorganized monads (Fig. 2U-Y), or in SEM images (e.g., Figs 4B-E, 5A \& B). The main difference in lorica appearance was the lack of spines on their surface (Figs 2J-Y, 3A-I, 4A-F \& 5A-F). None of the laboratory cultured loricae had spines on their surface or around the apical pore. Some of the mature loricae had very small warts visible in SEM images that resembled spines, that were distributed on the lorica surface (Fig. 4C \& F). We did not see any spines either in young or old envelopes nor in any of the envelopes observed using light microscopy. This was unexpected, as $T$. hispida from natural populations possess spines over the whole surface of the envelope (Fig. 1A-J). A collar around the apical pore is a distinguishing feature of T. hispida var. crenulatocollis, which is one of the most common varieties of T. hispida, while the nominative variety-hispida-does not have a collar. In our study, we observed loricae without collars (Fig. 2K \& L); however, the majority did have collars. Some of the loricae formed a very short collar (Fig. 2M, O, Q, R \& Y), while others were longer, and often denticulated around the rim (Figs 2P, S-U, 3B, $C \&$ F).

We observed loricae in different stages of development during the 4 weeks of the study. Initially, the cells did not possess loricae (Figs 2F, G \& 3A). Young loricae were very thin and fragile (Fig. $2 \mathrm{H} \& \mathrm{I}$ ) and, in the SEM images, reticulated (Fig. 3B-I) with larger pores at first, which became denser (Fig. 3G-I). At this stage, the envelope wall 

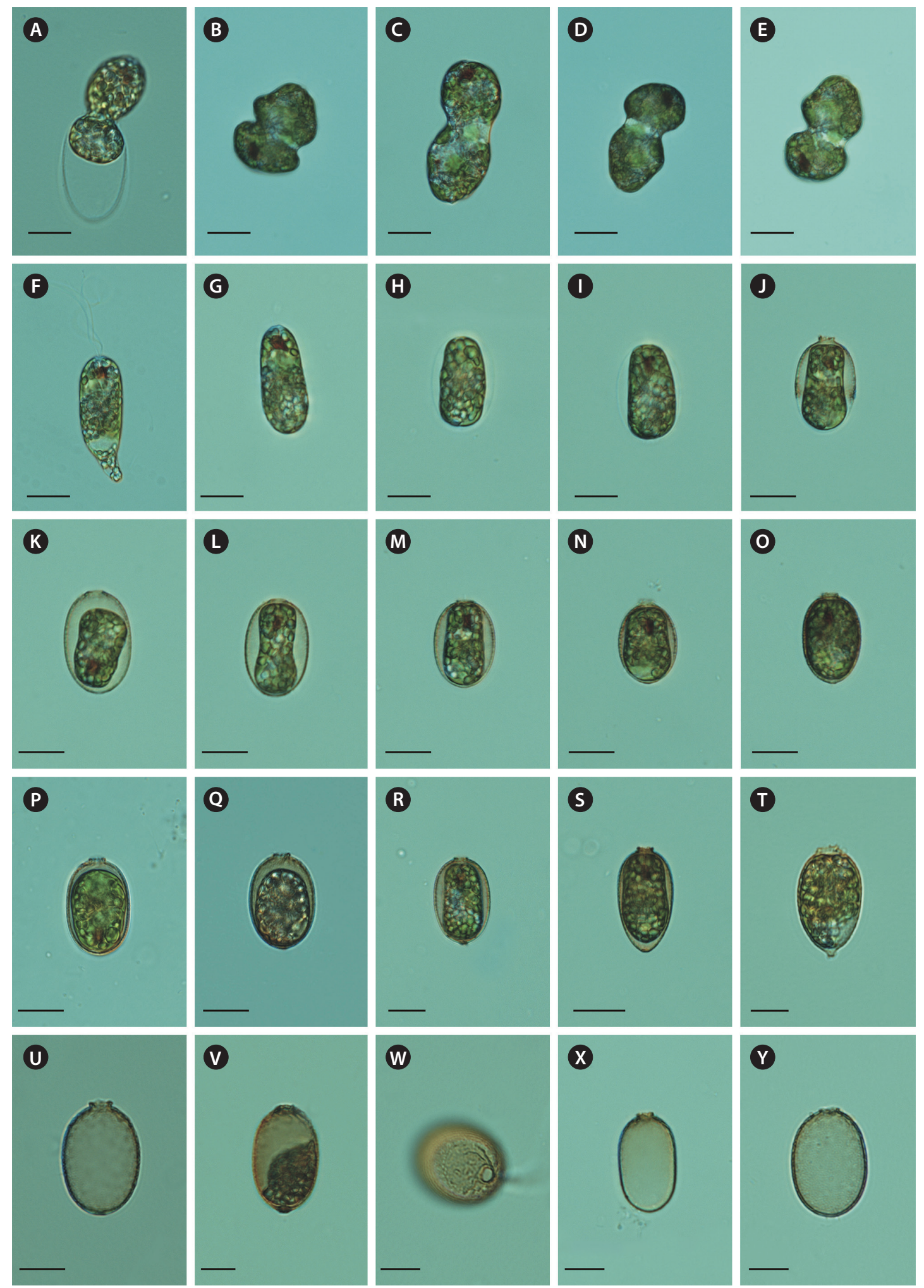

Fig. 2. Appearance of Trachelomonas hispida (CCAP 1283/8, Culture Collection of Algae \& Protozoa, Oban, Scotland, UK). (A) Monad leaving lorica. (B-E) Monads in dividing process. ( $F \&$ G) Young monads after division. (H \& I) Young monads in thin, hyaline loricae. (J) Mineralization process from the apical end to the posterior. (K-T) Monads in loricae of a different appearance. Oval (K-R) and obovoid (S \& T), without collar (K$M)$, or with it (N \& T), without posterioral cauda (K-Q \& S) or with it (R \& T). (U-Y) Empty loricae of a different appearance. All cells come from the culture samples maintained in Jaworski's medium with soil extract. Scale bars represent: A-Y, $10 \mu \mathrm{m}$. [Colour figure can be viewed at http://www. e-algae.org]. 

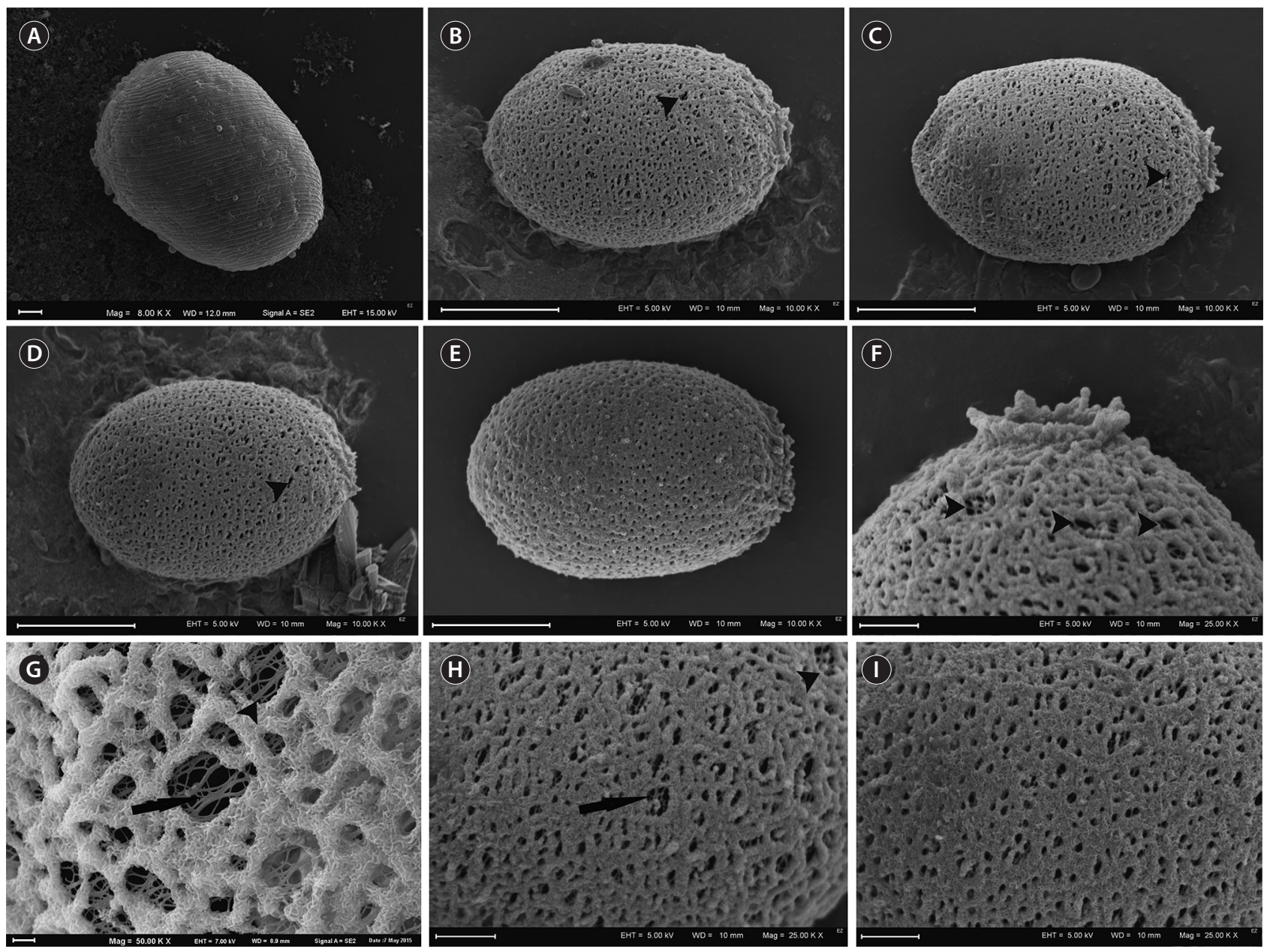

Fig. 3. Structural details (scanning electron microscopy pictures) of young loricae in Trachelomonas hispida (CCAP 1283/8, Culture Collection of Algae \& Protozoa, Oban, Scotland, UK). (A) Young cells, after division, are naked, with no lorica. Afterwards, cells produce thin loricae with larger "holes" (B-D, F \& H) (arrowheads), which became denser (E \& I). At this stage, the envelope wall has two layers, including an inner, reticulated region (arrows) and outer, developing granular region. Scale bars represent: $A, F, H$ \& I, $2 \mu \mathrm{m} ; \mathrm{B}-\mathrm{E}, 10 \mu \mathrm{m} ; \mathrm{G}, 300 \mathrm{~nm}$.

had two layers, including an inner, reticulated region and outer, developing granular region (Fig. 3G \& H). Then, when adult, the cells formed solid, thick walls of a granular structure with small pores (Figs 4A-F, 5A \& B). At the end of the formation process, the wall became thicker in well-developed envelopes and the inner reticulate region was no longer visible. As the loricae aged, they changed their shapes slightly (Fig. 5C-F), and rope-like fibres from the external layer started to unwind and expose the underlying net-like reticulum (Fig. 5F), progressing from the apical pore and becoming somewhat wrinkled. The wall of the loricae became reticulate again, but without a dense, granular layer, and with a very loose structure with very large perforations (Fig. 5D \& F).

As aforementioned, none of the loricae formed spines on their surfaces, either those from control conditions or those cultivated in filtered water from natural water bodies. Although physicochemical features of the lake water differed (Table 1), none of the loricae formed spines. Loricae in samples from natural water bodies showed similar variation in shape (formation of a collar, folds around the apical pore, or a process at the posterior end) as those from the control samples (Fig. 6A-T). In samples from lake Rotcze, the cells showed very thin, hyaline loricae (Fig. $6 \mathrm{~N} \& \mathrm{O}$ ) or did not present a regular envelope at all (Fig. 6U). 

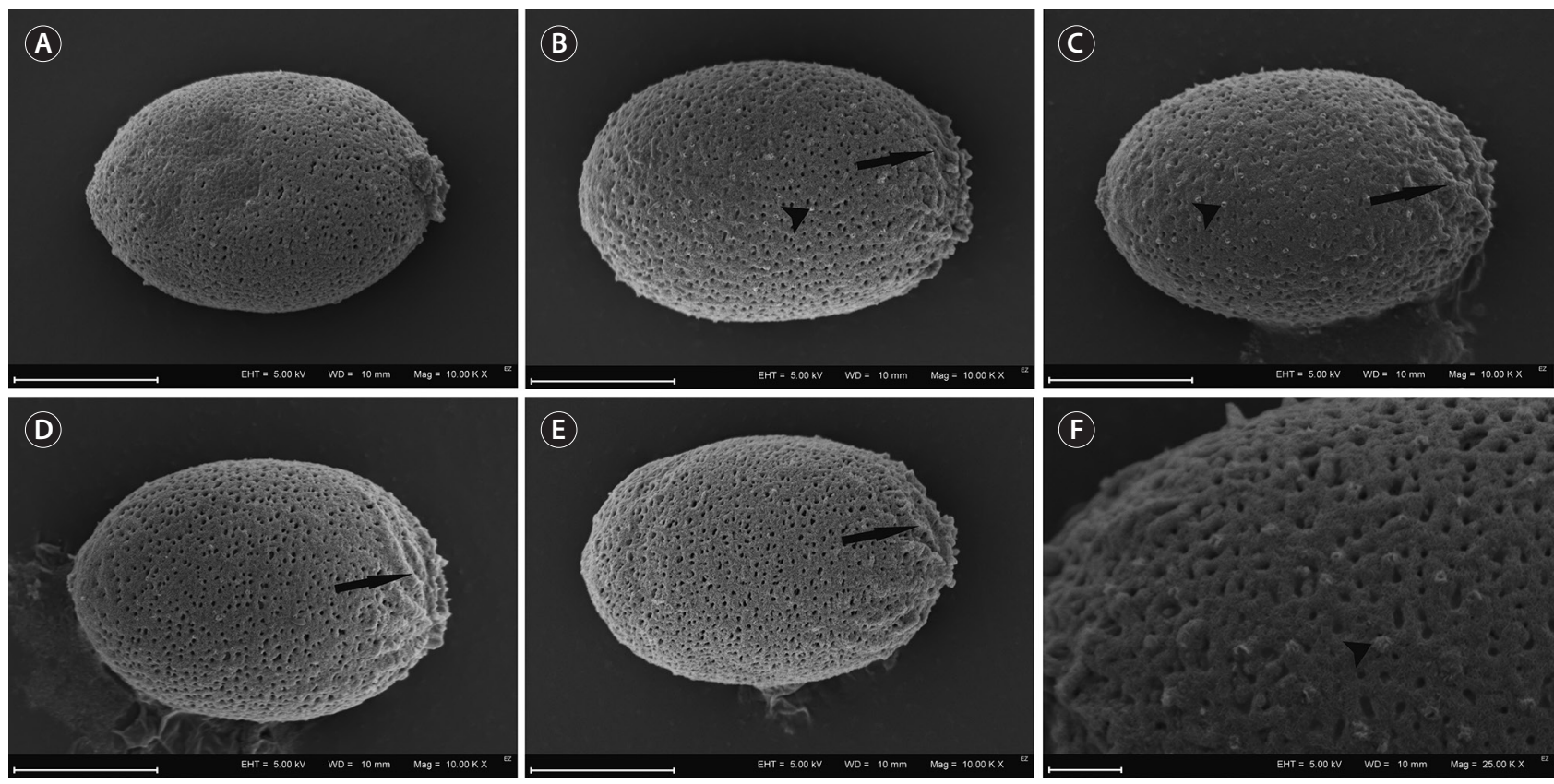

Fig. 4. Structural details (scanning electron microscopy pictures) of adult loricae in Trachelomonas hispida (CCAP 1283/8, Culture Collection of Algae \& Protozoa, Oban, Scotland, UK). Loricae developed various structures on loricae. Some of them have a collar around the apical porus (A), the other have spiral ribs around the porus ( $B-E$, arrows), or small granules on the lorica wall ( $B, C$ \& $F$, arrowheads). Scale bars represent: $A-E$, 10 $\mu \mathrm{m} ; \mathrm{F}, 2 \mu \mathrm{m}$.
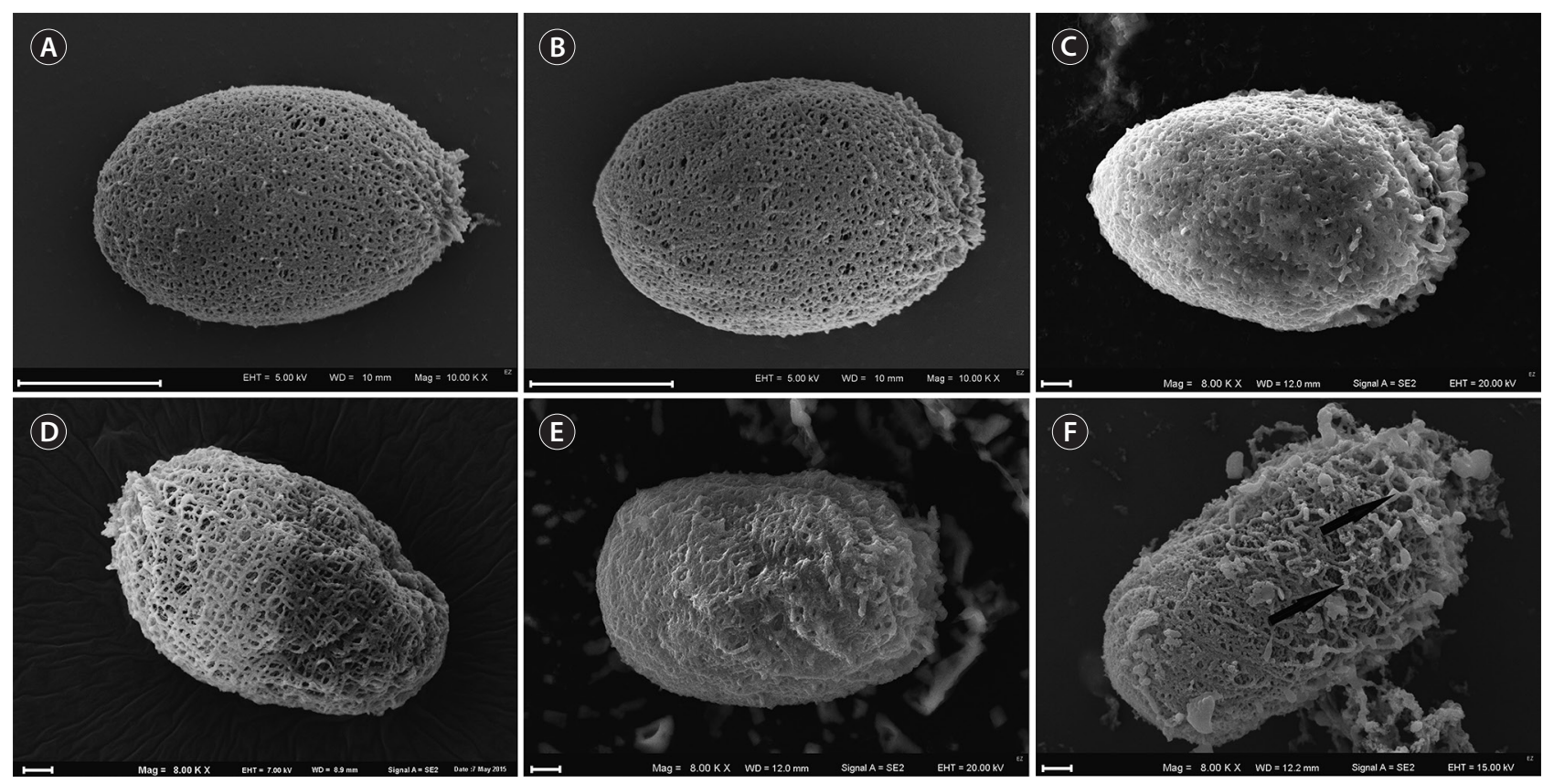

Fig. 5. Structural details (scanning electron microscopy pictures) of old loricae in Trachelomonas hispida (CCAP 1283/8, Culture Collection of Algae \& Protozoa, Oban, Scotland, UK). (A-E) At this stage loricae have ribs and a collar around the apical pore. They start changing their shapes slightly (C-F), and rope-like fibres from the external layer started to unwind ( $F$, arrows) and expose the underlying net-like reticulum. Scale bars represent: A-C, $10 \mu \mathrm{m}$; D-F, $2 \mu \mathrm{m}$. 

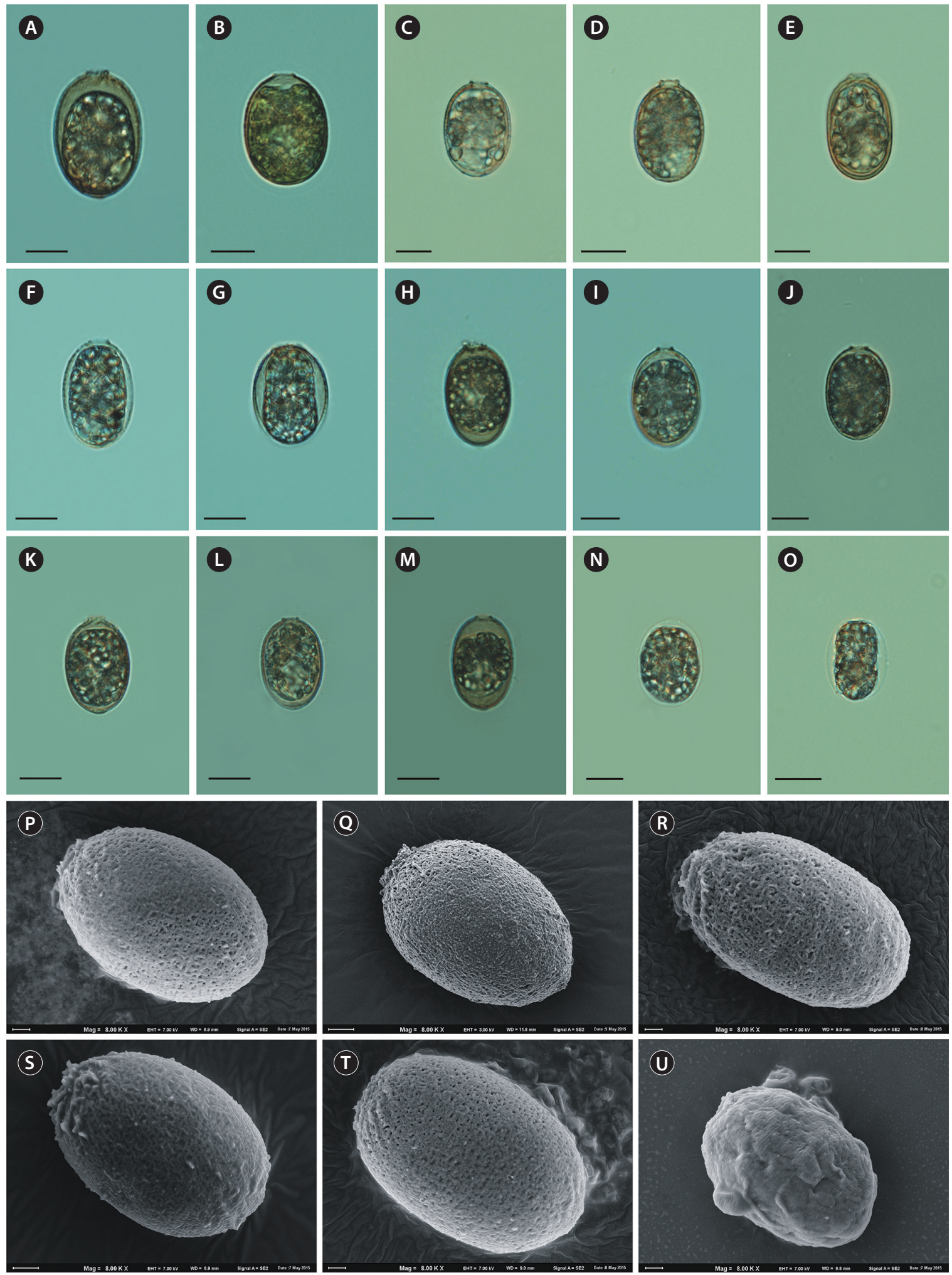

Fig. 6. Variability of Trachelomonas hispida (CCAP 1283/8, Culture Collection of Algae \& Protozoa, Oban, Scotland, UK) cultivated in water from various water bodies. (A-O) Light microscopy pictures. (P-U) Scanning electron microscopy pictures. They present a different appearance to some extent, but no has spines on lorica wall. (A-E \& P) Control samples cultivated in Jaworski's medium with soil extract. (F, G \& Q) Glinki Lake. (H, I \& R) Piaseczno Lake. (J, K \& S) Sumin Lake. (L, M \& T) Zalew Zemborzycki dam reservoir. (N, O \& U) Rotcze Lake. Scale bars represent: A-O, $10 \mu m$; P, R-U, $2 \mu \mathrm{m} ; \mathrm{Q}, 3 \mu \mathrm{m}$. [Colour figure can be viewed at http://www.e-algae.org]. 


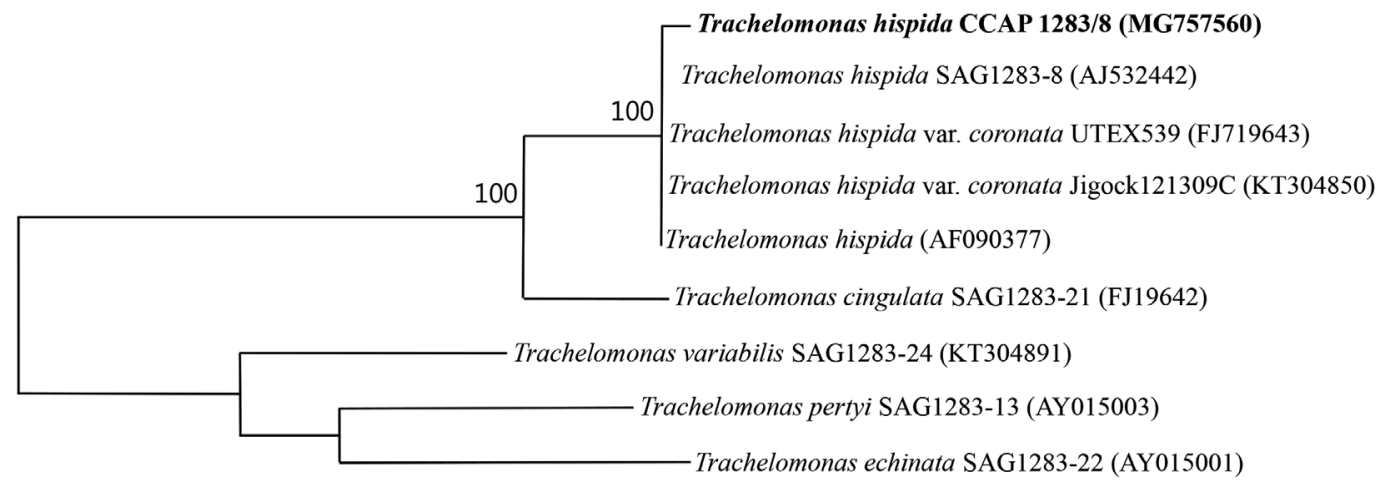

0.01

Fig. 7. Phylogenetic relationships of the Trachelomonas hispida CCAP $1283 / 8$ and the reference Trachelomonas strains based on small nuclear subunit of the ribosomal RNA sequences. Bootstrap values $\geq 70 \%$ were given at the branching points. The scale bar indicates the number of nucleotide substitutions per site.

\section{Molecular analysis}

Due to the unusual appearance of the loricae in this study (spineless, with folds around the apical pore, some with a small process at the posterior end), we conducted molecular identification based on the SSU gene of T. hispida CCAP 1283/8. The PCR product containing nearlywhole-length sequences of the 18S rRNA gene $(2,067 \mathrm{bp})$ displayed the highest (99.7\%) sequence identity to the available sequences of $T$. hispida, $96.6 \%$ sequence identity to that of Trachelomonas cingulata, and relatively low sequence identity $(<90 \%)$ to the sequences of other Trachelomonas species. The phylogenetic analysis of the selected members of this genus based on SSU gene sequences showed an apparent monophyletic group formed from the Trachelomonas CCAP 1283/8 strain and strains belonging to $T$. hispida, which confirmed its taxonomic affinity to T. hispida (Fig. 7).

\section{Element composition}

A SEM-energy dispersive spectroscopy analysis showed differences in the chemical composition of T. hispida loricae, depending on their structure (granular or reticulate) (Table 2). Regardless of envelope structure, envelopes were generally composed of Fe and / or Mn that were the main mineralizing elements in trachelomonad loricae. However, the amounts of both Fe and Mn differed in cells of different ages (Table 2). Young, reticulate loricae were mineralized with Fe and did not contain Mn. Conversely, older loricae contained $\mathrm{Mn}$ and did not contain Fe. Most of the well-developed loricae, which had solid structures with small pores, were saturated with Fe (high amount) and Mn (smaller amount) (Table 2).

Although the results showed large variation in loricae shapes within one species, the question remains over the lack of spines on loricae surfaces in cells cultivated under laboratory conditions. In previous studies (unpublished), we observed only one envelope with spines. Future questions to consider include: why do loricae not develop spines under laboratory conditions; and what role do spines play in natural environments? These questions require further and broader inquiry. Although it is still under investigation, no direct answers are currently available.

Table 2. Relative amounts of the main elements in envelopes of trachelomonads

\begin{tabular}{cccccccrr}
\hline EDS analysis & C (\%) & Al (\%) & Si (\%) & P (\%) & K (\%) & Fe (\%) & Na (\%) & Mn (\%) \\
\hline 0 & - & $4.63 \pm 0.19$ & $67.65 \pm 0.36$ & - & $8.70 \pm 0.23$ & - & $10.47 \pm 0.17$ & - \\
1 & $54.15 \pm 4.87$ & $0.79 \pm 0.06$ & $0.07 \pm 0.01$ & $0.61 \pm 0.05$ & $0.83 \pm 0.05$ & $2.79 \pm \mathbf{0 . 0 9}$ & $4.62 \pm 0.27$ & - \\
2 & $54.85 \pm 4.81$ & $0.51 \pm 0.05$ & $0.15 \pm 0.03$ & $1.11 \pm 0.06$ & $0.59 \pm 0.04$ & $\mathbf{5 . 6 1 \pm 0 . 1 5}$ & $3.57 \pm 0.20$ & $\mathbf{0 . 5 6} \pm \mathbf{0 . 0 4}$ \\
3 & $68.68 \pm 7.70$ & $0.45 \pm 0.05$ & $0.15 \pm 0.03$ & $0.36 \pm 0.04$ & $0.08 \pm 0.03$ & - & $0.87 \pm 0.09$ & $\mathbf{0 . 8 8} \pm \mathbf{0 . 0 6}$ \\
\hline
\end{tabular}

Data in bold are for the ions considered as the main components in trachelomonads' loricae. Values are presented as mean \pm standard error. 0 , energy dispersive spectroscopy (EDS) analysis for basal glass; 1 , young, reticulated loricae; 2 , solid, granulated loricae; 3 , old loricae. 


\section{DISCUSSION}

\section{Morphology of loricae}

In this study, we observed cells of T. hispida (CCAP 1283/8) cultivated in JM : SE and water from six natural water bodies filtered through a GF/C and a $0.22-\mu \mathrm{m}$ Millipore syringe filter at different stages of development. We observed that young cells possessed elliptical loricae, with very thin walls that were largely perforated. The very young, hyaline loricae were smooth and had no processes at the posterior end, or any collars, folds, or spines around the apical pore. These observations concurred with those of Brosnan et al. (2005), who reported that young loricae excreted a layer of mucilage over the entire protoplast, followed by the formation of the collar at the anterior end. However, we observed that in some cells the subsequent mineralization process did not proceed equally over the entire lorica, but began at the apical end and progressed to the posterior end. This observation was unexpected, as Leedale (1975) stated that envelope development was equal all around the cell, and that there was no localized "growing point." Brosnan et al. (2005) also confirmed this, and concluded that the equal pattern of lorica formation is one of the features that distinguishes Trachelomonas from Strombomonas. However, our observations showed that other patterns of lorica mineralization also occur.

In mature loricae, collars, folds, and processes were present, and only a few regularly elliptic loricae lacked these structures. We suggest that these kinds of structures appear as the cell ages. At the end of its lifecycle, the structure of the lorica becomes looser, and single external strands unwind and expose the inner net-like layer of loricae. No loricae had spines, irrespective of the age of their envelopes. This phenomenon is difficult to explain, but it has been reported before (West and Walne 1980, Kim et al. 1999). West and Walne (1980) stressed that ornamental heterogeneity within one culture cannot be associated with mineral impregnation as they observed loricae of different appearances within the same culture. This suggests that different morphology depends on the age of the cell and physicochemical conditions and, possibly, biological drivers.

The developmental stages of loricae produce a great variety of objects. A similar observation was made over 100 years ago by Playfair (1915), who reported that varieties of Trachelomonas volzii were only the developmental stages of $T$. volzii var. australis. Therefore, a proper identification of variety, form, or even species depends on the developmental stage of the cell. Field specimens that fulfil the descriptions in the key guides for T. hispida are identified as T. hispida and they always have spines. There are some exceptions: the varieties macropunctata and granulata, which were described 100 years ago (Skvortsov 1919 and Playfair 1915, respectively), although there have been no new records of them since. The loricae that do not produce spines or have warts on the lorica surface might be different species, e.g., Trachelomonas planctonica, Trachelomonas nigra, or Trachelomonas abrupta, especially if there is no information about chloroplasts. It is easier to observe variation in lorica in culture conditions using the strain T. hispida. Such a large variation in lorica appearance within one strain suggests that many widespread infraspecific taxa, such as T. hispida var. crenulatocollis, $T$. hispida var. coronata, $T$. hispida var. spinulosa, and T. hispida var. acuminata, which are all extremely similar to each other, should be recognized as T. hispida var. hispida. Moreover, the differences between varieties are, in our opinion, negligible, which was suggested almost 20 years ago by Kim et al. (1999). Kim et al. (1999) investigated many cells from natural water bodies in Korea that were cultured under laboratory conditions, and showed great variation in envelopes within T. hispida loricae with and without spines, all with the well-developed crenulate or spiny collars. Our results concurred with Kim et al. (1999) and we also suggest reducing the number of varieties within this species. In our opinion, the phenotypic variation in T. hispida is large and numerous varieties or forms (often unchecked) appear to be the same species. The high level of plasticity of cells also applies to other species within the Trachelomonas genus, e.g., Trachelomonas caudata that has highly variable loricae, from densely spiny to completely spineless. This could explain why the number of taxa has recently been reduced (Wołowski et al. 2016). There is similar taxonomic ambiguity over T. volzii and Trachelomonas dubia, which are extremely similar to each other and have vague diagnostic features (Poniewozik et al. 2018). Environmental drivers and their interactions can trigger cells to change their morphology (Pringsheim 1953, Leedale 1975, West and Walne 1980, Padisák et al. 2003, Reynolds 2007). Therefore, it is unhelpful to describe new taxa based on size, or small, changeable features of morphology, as this causes additional ambiguity for researchers working on field samples. Unfortunately, we did not observe meaningful changes in lorica appearance in our cultures of the strain in GF/C- and Milliporefiltered water from different water bodies. Although the water had different physical chemical properties, e.g., 
water from one lake had brown colour and high dissolved organic carbon content, the others were differentiated taking into account inorganic phosphorus and especially ammonium nitrogen concentration (Table 1), it did not have a meaningful importance on lorica appearance. The cells cultivated in the lake waters had no spines on their surfaces and formed a collar of different forms, folds around the apical pore, and sometimes small processes at the posterior end. However, the cells maintained in water from Lake Rotcze did not form regular loricae or they were hyaline and poorly mineralized (Fig. 6N, O \& $\mathrm{U})$. This suggested that there were insufficient mineral components in the water to physiologically process into fully developed loricae. This statement especially applies $\mathrm{Fe}, \mathrm{Mn}$, and Ca salts that are considered to be the main compounds in lorica formation and mineralization (Pereira et al. 2003). The remaining loricae were similar in outline and external structure to the control samples (maintained in JM : SE). Further studies are needed to discern the relationship between chemical components in the water, physical appearance, and element composition of trachelomonad loricae.

\section{Element composition}

Studies of the elemental composition of T. hispida loricae showed the presence of two basal elements: $\mathrm{Mn}$ and Fe. Other constituents of loricae included Si, P, S, $\mathrm{K}, \mathrm{Mg}, \mathrm{Al}$, and $\mathrm{Cl}$, which were reported in other studies (West et al. 1980a, Dunlap et al. 1986, Dunlap and Walne 1987, Conforti et al. 1994, Pereira and Azeiteiro 2003, Poniewozik 2017). West and Walne (1980) analysed the elemental composition of T. hispida var. coronata envelopes and demonstrated that $\mathrm{Mn}, \mathrm{Fe}, \mathrm{Si}, \mathrm{P}, \mathrm{S}, \mathrm{K}$, and Ca were major components, and a special cell selectivity for $\mathrm{Mn}$. The loricae also contained traces of $\mathrm{Mg}, \mathrm{Al}$, and $\mathrm{Cl}$ (West and Walne 1980). However, in our study, the elemental composition of young, mature, and old loricae differed to some extent, which might have been a result of different rates of incorporating and releasing microelements in and out of the lorica structure. West and Walne (1980) compared the composition of loricae at different stages of mineralization and categorized loricae into light, medium, and dark, which might conform to our young, mature, and old loricae (Table 2). In their study, the light loricae contained the least amount of Mn, whereas dark ones contained the most. In our study, young loricae had no Mn, while the oldest ones had a large amount of $\mathrm{Mn}$. Fe was present in young and mature loricae, which is probably because Fe compounds are necessary in the initial stages of cell and lorica formation (Pringsheim 1953). This author stated that adding Fe to the medium promoted cell proliferation. In turn, adding Mn compounds caused darkening of the envelopes, hence the incorporation of $\mathrm{Mn}$ is activated at a later stage of development. Since the incorporation of mineral compounds and the formation of a solid lorica occurs extracellularly, trachelomonads may be considered as model organisms to investigate the mechanism of biomineralization, as suggested by West et al. (1980a).

\section{The lack of spines and their hypothetical role}

Although the lack of spines in T. hispida in culture was unexpected, the underlying cause of this phenomenon has not been identified. Our results raised some questions-are the spines important for cells, why do they form, and what are the external stimuli that induce the changes in the envelope appearance? We suggest that the cause of the spineless phenomenon may be similar to that observed in species that produce mucilaginous envelopes (e.g., cyanobacteria or chlorophytes). Reynolds (2007) reported that typically mucilaginous species that are isolated and grown in culture conditions dispense with the formation of mucilage altogether. This was similar to our observations of trachelomonads that are known to be spiny in natural conditions, but do not often form spines in culture conditions. Similarly, Scenedesmus, which occurs in nature most often as a 4-cell coenobium, is very often unicellular in culture (Lürling and Van Donk 2000). We suggest that spines play an important role as cells can use them to both resist being caught and ingested by grazers and, perhaps, spines also reduce the sinking velocity. Trachelomonads, like most types of phytoplankton cells, are heavier than water, especially as they form structures similar to diatom frustules that are saturated with $\mathrm{Fe}, \mathrm{Mn}$, and $\mathrm{Si}$ compounds. We suggest that spines is one of the strategies to increase the surface area of the lorica and its buoyancy, which is very important in water bodies where trachelomonads are exposed to wind and water motion; however, these conditions are absent in culture conditions.

A study by West and Walne (1980) reported spineless loricae in T. hispida var. coronata in the majority of samples and some spiny loricae in cultures. Similarly, Kim et al. (1999) reported both kinds of envelopes. Padisák et al. (2003) studied how the shape of a cell or colony influences buoyancy and showed that all protuberances and spine arrangements of Staurastrum spp., Tetrastrum staurogeniaeforme, and Ceratium hirundinella increased 
form resistance-which is the main defence against sedimentation. They also claimed that oval-shaped flagellates Rhodomonas and Gymnodinium sank faster than spherical flagellates of equivalent volume (Padisák et al. 2003). Conversely, other trachelomonads, e.g., Trachelomonas similis, Trachelomonas volvocinopsis, or Strombomonas species flow and do not sink, even though they do not have spines, suggesting other factors might influence motility. T. similis has a long, curved collar, T. volvocinopsis is small and round, and Strombomonas species have wrinkled loricae that possibly help them to float. Spines might be a good adaptation to deter grazers similar to the mucilaginous sheaths of other organisms. The sheaths reduce the palatability of algae and make them too large for microzooplankters to ingest, and more difficult for mesoplanktonic raptors to grasp, and less filterable and more mechanically obstructive for filter-feeding cladocerans, although the larger the alga, the fewer potential direct consumers (Reynolds 2007).

The activity of grazers combined with grazer-associated chemical metabolites present in water bodies might explain phenotypic plasticity in the appearance of cells. Alternatively, the lorica itself appears to be a sufficient defence mechanism against predators. Different appearances of cells or colonies might also be a result of other factors, including responses to different physicochemical conditions (e.g., light, temperature, mineral salts, and / or nutrients) as was observed for Desmodesmus species (Shubert et al. 2014). Whatever the function of trachelomonad loricae and surface spines, little is known about their ecological advantages and disadvantages. However, it seems likely that they increase resistance to sinking and grazing.

In conclusion, the cells of Trachelomonas hispida formed fragile, thin loricae in the early stage of lorica development. The loricae had large perforations and formed short collars-this feature was typical of most of T. hispida growing in laboratory conditions. Well-developed cells had loricae of a solid, granular structure at the surface and a reticulate structure underneath. At the end of the formation process, the loricae became reticulate again, with a loose-structured envelope wall and some wrinkling. The possession of spines on the surface wall was not a permanent attribute of envelopes of T. hispida. The main mineralizing element in young loricae was Fe, while mature loricae with a granular structure contained both Fe and Mn. Old loricae were saturated mainly with Mn compounds.

\section{ACKNOWLEDGEMENTS}

We would like to thank our colleagues Dr. Wojciech Pęczuła and Prof. Konrad Wołowski for fruitful discussion concerning the possible role of spines on the lorica surface. We also thank Professor Elliot Shubert for substantive remarks on the manuscript and for helping in the English editing. This work was also partly supported by the European Union from the European Regional Development Fund under the Operational Programme Development of Eastern Poland 2007-2013 (POPW.01.03.0006-003/09-00).

\section{REFERENCES}

Bilan, M. I. \& Usov, A. I. 2001. Polysaccharides of calcareous algae and their effect on the calcification process. Russ. J. Bioorg. Chem. 27:2-16.

Bozzola, J. J. \& Russell, L. D. 1995. Electron microscopy: principles and techniques for biologists. Jones and Bartlett, Boston, MA, 542 pp.

Brosnan, S., Brown, P. J. P., Farmer, M. A. \& Triemer, R. E. 2005. Morphological separation of the euglenoid genera Trachelomonas and Strombomonas (Euglenophyta) based on lorica development and posterior strip reduction. J. Phycol. 41:590-605.

Conforti, V. 1999. A taxonomic and ultrastructural study of Trachelomonas Ehr. (Euglenophyta) from subtropical Argentina. Cryptogam. Algol. 20:167-207.

Conforti, V. 2010. Ultrastructure of the lorica of species (Euglenophyta) from New Jersey, USA. Algol. Stud. 135:1540 .

Conforti, V., Walne, P. L. \& Dunlap, J. R. 1994. Comparative ultrastructure and elemental composition of envelopes of Trachelomonas and Strombomonas (Euglenophyta). Acta Protozool. 33:71-78.

Darriba, D., Taboada, G. L., Doallo, R. \& Posada, D. 2012. jModeltest2: more models, new heuristics and parallel computing. Nat. Methods 9:772.

Dillard, G. E. 2000. Freshwater algae of the Southeastern United States. Part 7: Pigmented Euglenophyceae. Bibliotheca Phycologica. J. Cramer, Berlin, 135 pp.

Donnelly Barnes, L. S., Walne, P. L. \& Dunlap, J. R. 1986. Cytological and taxonomic studies of the Euglenales. I. Ultrastructure and envelope elemental composition in Trachelomonas. Br. Phycol. J. 21:387-397.

Duangjan, K. \& Wołowski, K. 2013. New taxa of loricate euglenoids Strombomonas and Trachelomonas from Thailand. Pol. Bot. J. 58:337-345. 
Dunlap, J. R. \& Walne, P. L. 1985. Fine structure and biomineralization of the mucilage envelopes of Trachelomas lefevrei (Euglenophyceae). J. Protozool. 32:437-441.

Dunlap, J. R. \& Walne, P. L. 1987. Variations in envelope morphology and mineralization in Trachelomonas lefevrei (Euglenophyceae). J. Phycol. 23:556-564.

Dunlap, J. R., Walne, P. L. \& Bentley, J. 1983. Microarchitecture and elemental spatial segregation of envelopes of Trachelomonas lefevrei (Euglenophyceae). Protoplasma 117:97-106.

Dunlap, J. R., Walne, P. L. \& Kivic, P. A. 1986. Cytological and taxonomic studies of the Euglenales. II. Comparative microarchitecture and cytochemistry of envelopes of Strombomonas and Trachelomonas. Br. Phycol. J. 21:399-405.

Ellegaard, M., Lenau, T., Lundholm, N., Maibohm, C., Friis, S. M. M., Rottwitt, K. \& Su, Y. 2016. The fascinating diatom frustules: can it play a role for attenuation of UV radiation? J. Appl. Phycol. 28:3295-3306.

Francillon-Vieillot, H., De Buffrénil, V., Castanet, J., Géraudie, J., Meunier, F. J., Sire, J. Y., Zylberberg, L. \& De Ricqlès, A. 1990. Microstructure and mineralization of vertebrate skeletal tissues. In Carter, J. G. (Ed.) Skeletal Biomineralization: Patterns, Processes and Evolutionary Trends. Vol. 1. Van Nostrand Reinhold, New York, pp. 471-530.

Hall, T. A. 2011. BioEdit: An important software for molecular biology. GERF Bull. Biosci. 2:60-61.

Hamm, C. E., Merkel, R., Springer, O., Jurkojc, P., Maier, C., Prechtel, K. \& Smetacek, V. 2003. Architecture and material properties of diatom shells provide effective mechanical protection. Nature 421:841-843.

Hildebrand, M. \& Lerch, S. J. 2015. Diatom silica biomineralization: parallel development of approaches and understanding. Semin. Cell Dev. Biol. 46:27-35.

Kim, J. -T., Shin, W. \& Boo, S. -M. 1999. A taxonomic reappraisal of Trachelomonas hispida (Euglenophyceae) from Korean Inland waters. Algae 14:1-7.

Kimura, M. 1980. A simple method for estimating evolutionary rates of base substitutions through comparative studies of nucleotide sequences. J. Mol. Evol. 16:111120.

Leedale, G. F. 1975. Envelope formation and structure in the euglenoid genus Trachelomonas. Br. Phycol. J. 10:17-41.

Łukomska-Kowalczyk, M., Karnkowska, A., Krupska, M., Milanowski, R. \& Zakryś, B. 2016. DNA barcoding in autotrophic euglenids: evaluation of COI and $18 \mathrm{~S}$ rDNA. J. Phycol. 52:951-960.

Lürling, M. \& Van Donk, E. 2000. Grazer-induced colony formation in Scenedesmus: are there costs to being colonial? Oikos 88:111-118.
Milligan, A. J. \& Morel, F. M. M. 2002. A proton buffering role for silica in diatoms. Science 297:1848-1850.

Mitchell, J. G., Seuront, L., Doubell, M. J., Losic, D., Voelcker, N. H., Seymour, J. \& Lal, R. 2013. The role of diatom nanostructures in biasing diffusion to improve uptake in a patchy nutrient environment. PLoS ONE 8:e59548.

Müller, W. E. G. 2012. Silicon biomineralization: biology-biochemistry-molecular biology-biotechnology. Springer Science \& Business Media, Berlin, 340 pp.

Padisák, J., Soróczki-Pintér, E. \& Rezner, Z. 2003. Sinking properties of some phytoplankton shapes and the relation of form resistance to morphological diversity of plankton: an experimental study. Hydrobiologia 500:243-257.

Pentecost, A. 1991. Calcification processes in algae and cyanobacteria. In Riding, R. (Ed.) Calcareous Algae and Stromatolites. Springer, Berlin, pp. 3-20.

Pereira, M. J. \& Azeiteiro, U. M. M. 2003. Structure, organization and elemental composition of the envelopes of Trachelomonas (Euglenophyta): a review. Acta Oecol. 24(Suppl. 1):S57-S66.

Pereira, M. J., Azeiteiro, U. M. M., Gonçalves, F. \& Soares, A. M. V. M. 2003. Inorganic composition of the envelopes of Trachelomonas Ehr. (Euglenophyta). Acta Oecol. 24(Suppl. 1):S317-S324.

Playfair, G. I. 1915. The genus Trachelomonas. Proc. Linn. Soc. N. S. W. 40:1-41.

Poniewozik, M. 2016. The euglenoid genus Trachelomonas (Euglenophyta) from eastern Poland: study on morphology and ultrastructure of envelopes with comments on morphologically similar species. Phytotaxa 278:181-211.

Poniewozik, M. 2017. Element composition of Trachelomonas envelopes (Euglenophyta). Pol. Bot. J. 62:77-85.

Poniewozik, M., Wołowski, K. \& Piątek, J. 2018. Trachelomonas volzii vs T. dubia (Euglenophyceae): one or two separate species? Study on similarities and differences of the species. Phytotaxa 357:1-16.

Preisig, H. R. 1994. Siliceous structures and silicification in flagellated protists. In Wetherbee, R., Pickett-Heaps, J. D. \& Andersen, R. A. (Eds.) The Protistan Cell Surface. Springer, Vienna, pp. 29-42.

Pringsheim, E. G. 1953. Observations on some species of Trachelomonas grown in culture. New Phytol. 52:238-266.

Raven, J. A. \& Waite, A. M. 2004. The evolution of silicification in diatoms: inescapable sinking and sinking as escape? New Phytol. 162:45-61.

Reynolds, C. S. 2007. Variability in the provision and function of mucilage in phytoplankton: facultative responses to the environment. Hydrobiologia 578:37-45. 
Sandgren, C. D., Hall, S. A. \& Barlow, S. B. 1996. Siliceous scale production in chrysophyte and synurophyte algae. I. Effects of silica-limited growth on cell silica content, scale morphology, and the construction of the scale layer of Synura petersenii. J. Phycol. 32:675-692.

Shubert, E., Wilk-Woźniak, E. \& Ligęza, S. 2014. An autecological investigation of Desmodesmus: implications for ecology and taxonomy. Plant Ecol. Evol. 147:202-212.

Skvortsov, B. W. 1919. Notes on the agriculture botany and zoology of China. XXXI. On new Flagellate from Manchuria. J. North China Branch R. Asiat. Soc. 50:96-104.

Solórzano, G. G., Martinez, M. G. O., Vazquez, A. L., Garfias, M. B. M., Zuñiga, R. E. Q. \& Conforti, V. 2011. Trachelomonas (Euglenophyta) from a eutrophic reservoir in Central Mexico. J. Environ. Biol. 32:463-471.

Starmach, K. 1983. Euglenophyta - Eugleniny. Flora Stodkowodna Polski. Part 3. Państwowe Wydawnictwo Naukowe. Warszawa, Kraków, 563 pp.

Sviben, S., Kepčija, R. M., Vidaković-Cifrek, Ž., Perić, M. S., Kružić, P., Popijač, A. \& Primc, B. 2018. Chara spp. exhibit highly heterogeneous light adaptation, calcite encrustation and epiphyton patterns in a marl lake. Aquat. Bot. 147:1-10.

Tamura, K., Stecher, G., Peterson, D., Filipski, A. \& Kumar, S. 2013. MEGA6: Molecular Evolutionary Genetics Analysis version 6.0. Mol. Biol. Evol. 30:2725-2729.

Thompson, A. S., Rhodes, J. C. \& Pettman, I. 1988. Natural Environmental Research Council. Culture collection of algae and protozoa: catalogue of strains. Freshwater Bi- ology Association (U.K.), Ambleside, 22 pp.

Wang, Q. -X., Liu, H. -J., Yu, J., Sun, S. -Q., Zhang, D. -W. \& Bao, W. -M. 2003. Comparative studies on the fine structure and elemental composition of envelopes of Trachelomonas and Strombomonas (Euglenophyta). Acta Bot. Sin. 45:601-607.

West, L. K. \& Walne, P. L. 1980. Trachelomonas hispida var. coronata (Euglenophyceae). II. Envelope substructure. J. Phycol. 16:498-506.

West, L. K., Walne, P. L. \& Bentley, J. 1980a. Trachelomonas hispida var. coronata (Euglenophyceae). III. Envelope elemental composition and mineralization. J. Phycol. 16:582-591.

West, L. K., Walne, P. L. \& Rosowski, J. R. 1980b. Trachelomonas hispida var. coronata (Euglenophyceae). I. Ultrastructure of cytoskeletal and flagellar systems. J. Phycol. 16:489-497.

Wołowski, K. 1998. Taxonomic and environmental studies on euglenophytes of the Kraków-Częstochowa Upland (Southern Poland). Fragm. Florist Geobot. Pol. 6:1-192.

Wołowski, K. \& Hindák, F. 2003. Atlas of Euglenophytes. VEDA, Publishing House of the Slovak Academy of Sciences, Bratislava, $136 \mathrm{pp}$.

Wołowski, K., Poniewozik, M. \& Juráň, J. 2016. Morphological variability of loricae in Trachelomonas caudata complex (Euglenophyta). Cryptogam. Algol. 37:97-108.

Wołowski, K. \& Walne, P. L. 2007. Strombomonas and Trachelomonas species (Euglenophyta) from south-eastern USA. Eur. J. Phycol. 42:409-431. 